\title{
Sistem Deteksi Kualitas Beras Berdasarkan Warna Menggunakan Fuzzy C- Means Clustering Guna Membantu Tingkat Pegetahuan Masyarakat
}

\author{
Dewi Lestari, Nurul Fadillah, Ahmad Ihsan \\ Program Studi Teknik Informatika, Universitas Samudra, Meurandeh-Langsa 24416, Aceh
}

KEYWORDS

Beras, Clustering, Fuzzy C-Means.

\section{CORRESPONDENCE}

Phone:

E-mail:

\section{PENDAHULUAN}

Indonesia merupakan salah satu negara dengan penduduk yang bahan dasar makanan pokoknya adalah beras. Tidak hanya di Indonesia, sebagian besar penduduk dunia juga memilih beras sebagai bahan makanan pokok utama (Elmande and Widodo, 2012). Beras memegang peranan yang sangat penting dalam kehidupan bangsa Indonesia, bahkan sebagian besar bangsa Asia memilih komoditi beras sebagai bahan makanan pokoknya. Semakin tingginya konsumsi beras di Indonesia dapat memicu terjadinya perkembangan beras bebas produk(Agustina et al., 2012).Dengan semakin meningkatnya konsumsi beras di Indonesia, masyarakat yang cerdas harus lebih teliti dalam melihat warna beras, apakah beras tersebut memiliki mutu yang layak masak atau tidak. Tetapi faktanya, banyak masyarakat yang belum memiliki pengetahuan khusus tentang bagaimana warna beras yang layak untuk di masak. Teknonolgi informasi dapat dimanfaatkan untuk membantu menyelesaikan masalah ini, khusususnya bagi masyarakat.

Di era teknologi informasi dan komunikasi, deteksi dan pengenalan obyek pada citra sudah banyak di kembangkan. Melalui bentuk, warna dan tekstur obyek yang dapat dikenali. Karena bentuk, warna dan tekstur objek satu dengan yang lainnya memiliki perbedaan. Misalnya warna buah cokelat muda dengan buah cokelat tua, bentuk angka 0 dan angka 1, dan tekstur cangkang kulit telur dengan kulit pepaya juga berbeda(Ilmiah, 2017). Dalam hal ini objek yang di gunakan yaitu warna beras. Parameter yang di gunakan penulis dalam mendeteksi penentuan warna beras adalah dengan membandingkan 2 warna beras berbeda dalam satu jenis beras. Salah satu metode yang dapat digunakan untuk menyelesaikan permasalahan ini adalah metode Fuzzy C-Means. Algoritma 
Fuzzy C-Means merupakan satu algoritma yang mudah dan sering di gunakan dalam pengelompokkan data karena membuat suatu perkiraan yang efisien dan tidak memerlukan banyak parameter (Pravitasari, 2009). Beberapa penelitian telah menghasilkan kesimpulan bahwa metode Fuzzy C-Means untuk mengelompokkan data berdasarkan atribut-atribut tertentu.

Pada kasus penelitian ini akan menganalisis penerapan metode Fuzzy C-Means untuk mengelompokkan beras bagus dan beras tidak bagus berdasarkan warna beras. Pada penelitian sebelumnya, (Utomo, 2016) melakukan sistem klasifikasi jenis beras menggunakan metode Learning Vector Quantization untuk menentukan klasifikasi beras putih dan beras ketan putih. Pada umumnya beras digunakan untuk bahan makanan pokok dimasak menjadi nasi, sedangkan ketan sering digunakan untuk bahan pembuatan kue. Oleh karena itu diharapkan tidak akan tertukar antara beras putih dan beras ketan.

\section{METODOLOGI PENELITIAN}

Penelitian ini dilaksanakan melalui beberapa tahapan yang akan di tunjukkan pada Gambar 1.

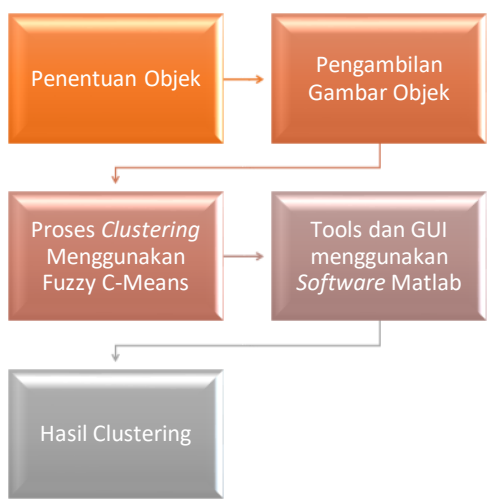

Gambar 1. Diagram alir tahapan penelitian

\section{Penentuan Objek}

Sebelum menentukan objek penelitian, terlebih dahulu mengumpulkan data dan informasi untuk memilih sebuah objek dan mencari bahan materi yang berhubungan dengan permasalahan yang akan di angkat(Pravitasari, 2009).

\section{Pengambilan Gambar Objek}

Dalam pengambilan gambar objek yang telah di tentukan harus menggunakan benda untuk pengambilan gambar yang baik. Benda yang di gunakan dapat berupa camera digital maupun kamera handphone. Hendaknya pengambilan gambar dapat menggunakan pixel yang tinggi, karena semakin tinggi pixel sebuah kamera maka aka semakin bagus gambar objek yang di hasilkan.

\section{Algoritma Clustering}

Secara umum pembagian algoritma clustering dibagi menjadi beberapa bagian yaitu Hierarchical clustering, Divisive hierarchical, dan Partitional clustering. Masing-masing algoritma clustering memiliki kelebihan dan kekurangannya masing-masing (Muhardi and Nisar, 2015)

\section{Algoritma Fuzzy C-Means Clustering (FCM)}

Salah satu teknik fuzzy clustering adalah Fuzzy C-Means Clustering (FCM). FCM merupakan suatu teknik pengklasteran data yang keberadaan setap datanya dalam suatu cluster di tentukan oleh nilai/derajat keanggotaan tertentu (Muhardi and Nisar, 2015). Teknik ini pertama kali diperkenalkan oleh Jim Bezdek pada tahun 1981. Dalam FCM setiap data bisa menjadi anggota dari beberapa cluster. Konsep dasar Fuzzy C-Means yang pertama ialah menentukan pusat cluster. Kondisi awal pada pusat cluster ini masih belum akurat tiap data memiliki derajat keanggotaan untuk tiap-tiap cluster. Dengan cara memperbaiki pusat cluster dan nilai keanggotaan tiap data secara berulang maka akan dapat dilihat bahwa pusat cluster akan bergerak menuju lokasi yang tepat. Perulangan ini didasarkan pada minimisasi fungsi obyektif yang menggambarkan jarak dari titik data yang diberikan ke pusat cluster yang terbobot oleh derajat kenggotaan titil data tersebut (Handayani et al., 2011). Fungsi objectif yang digunakan pada FCM yaitu:

$$
J_{w}=(\mathrm{U}, \mathrm{V} ; \mathrm{X})=\sum_{k-1}^{n} \quad \sum_{i-=1}^{c} \quad\left(\mu_{i k}\right)^{w}\left(d_{i k}\right)^{2}
$$

dengan $+\in, 1, \infty)$

$$
d_{i k}=d\left(x_{k}-v_{i}=\left[\begin{array}{ll}
\sum_{j=1}^{m} & \left(x_{k j}-x_{i j}\right)
\end{array}\right]^{\frac{1}{2}}\right.
$$

$\mathrm{x}$ adalah data yang akan di klaster :

$$
X=\left[\begin{array}{ccc}
x_{11} & \cdots & x_{1 m} \\
\vdots & \ddots & \vdots \\
x_{n 1} & \cdots & x_{m m}
\end{array}\right]
$$

Dan v adalah matrks pusat cluster :

$$
X=\left[\begin{array}{ccc}
v_{11} & \cdots & v_{1 m} \\
\vdots & \ddots & \vdots \\
v_{m 1} & \cdots & v_{m m}
\end{array}\right]
$$

nilai $J_{w}$ terkecil adalah yang terbaik sehingga:

$$
J_{w}^{*}\left(U^{*}, U^{*} ; x\right)=\min J(U, U ; x)
$$

jika $\quad d_{i k}>0, \forall i, k ; w>1$ dan $X$ setidaknya memiliki $m$ elemen, maka $(\mathrm{u}, \mathrm{v}) \in M_{f m}>0, \forall i, k ; w$ dapat meminimasi $J_{w}$ hanya jika:

$$
\mu_{i k}=\frac{\left.\sum_{j=1}^{m}(x i j-v k j)^{2}\right]^{\frac{-1}{w-1}}}{\sum_{i=1}^{n}\left[\sum_{j=1}^{m}\left(x_{i j}-v_{k j}\right)^{2}\right]^{\frac{-1}{w-1}}} ;
$$

dan

$v_{k j}=\frac{\sum_{i=1}^{n}\left(\left(\mu_{i k}\right)^{w} * X_{i j}\right)}{\sum_{i=1}^{n}\left(\mu_{i k}\right)^{w}} ; 1 \leq i \leq m ; 1 \leq J \leq m(7)$

Algotitma Fuzzy C-Means (FCM) diberikan sebagai berikut :

1. Menentukan data yang akan di cluster $X$, berupa matriks berukuran $\mathrm{n} \times \mathrm{m}(\mathrm{n}=$ jumlah sampel data, $\mathrm{m}=$ atribut setiap data ). Xij = data sampel ke-I $(i=1,2 \ldots, n)$,atribut ke-j $(j=1,2, \ldots, m)$.

2. Menentukan :

- Jumlah cluster $\quad=\mathrm{c}$

- Pangkat =W

- $\quad$ Maksimum interasi $=$ Maxltr

- $\quad$ Error terkecil yang di harapkan $=\zeta$

- Fungsi objektif awal $=\mathrm{P}_{0}=0$ 
- Interasi awal $\quad=\mathrm{t}=1$

3. Membangkitkan bilangan random $\mu \mathrm{ik}, \mathrm{i}=1,2,3 \ldots \mathrm{c}$; sebagai elemen-elemen matriks partisi awal $U$.

Menghitung jumlah setiap kolom :

$$
Q_{i}=\sum_{k=1}^{c} \mu_{i k}
$$

dengan $\mathrm{j}=1,2, \ldots \mathrm{n}$.

Menghitung :

$\mu_{i k}=\frac{\mu_{i k}}{Q_{i}}$

4. Menghitung pusat cluster ke-k : $\mathrm{V}_{\mathrm{kj}}$, dengan $\mathrm{k}=1,2, \ldots \mathrm{c} ;$ dan $\mathrm{j}=1,2, \ldots \mathrm{m}$

$$
V_{k j}=\frac{\sum_{i=1}^{n}\left(\left(\mu_{i k}\right)^{w} * x_{i j}\right.}{\sum_{i=1}^{n}\left(\left(\mu_{i k}\right)^{w}\right.}
$$

5. Menghitung fungsi objektif pada interasi ke-t :

$$
P_{t}=\sum_{i=1}^{n} \sum_{k}^{c}\left(\left[\sum_{j=1}^{m}\left(X_{i j}-V_{k j}\right)^{2}\right]\left(\mu_{i k}\right)^{w}\right)
$$

6. Menghitung perubahan matriks partisi:

$$
\mu_{k j}=\frac{\left[\sum_{j=1}^{m}\left(x_{i j}-v_{k j}\right)^{2}\right]^{\frac{-1}{w-1}}}{\sum_{k=1}^{c}\left[\sum_{j=1}^{m}\left(x_{i j}-v_{k j}\right)^{w}\right]^{\frac{-1}{w-1}}}
$$

\section{Proses Clustering dengan Fuzzy C-Means}

Dalam tahap ini akan diterapkan metode Fuzzy C-Means untuk menentukan kualitas beras. Hasil penentuan ini kemudian akan digunakan untuk pertimbangan dalam menentukan beras kualitas dengan kualitas yang baik. Berikut algoritma Fuzzy C-Means Clustering dalam menentukan kualitas beras :

1. Menetapkan matriks partisi awal $U$ berupa matriks berukuran $\mathrm{n}$ x $\mathrm{m}$ (n adalah jumlah sampel data, yaitu $=2$, dan $\mathrm{m}$ adalah parameter/atribut setiap data, yaitu=1). $\mathrm{X}_{\mathrm{ij}}=$ data sampel ke-i $(\mathrm{i}=1,2, \ldots, \mathrm{n})$, atribut ke-j $(j=1,2, \ldots, m)$.

2. Menentukan Nilai Parameter Awal :

- $\quad$ Jumlah cluster (c) $\quad=2$

- Pangkat/bobot (w) =

- $\quad$ Maksimum iterasi (MaxIter) $=100$

- $\quad$ Error terkecil yang diharapkan $(\xi)=10^{-5}$

- Fungsi objektif awal $\left(\mathrm{P}_{\mathrm{O}}\right) \quad=0$

- Interasi awal (t) $\quad=1$

3. Membangkitkan bilangan random $\mu \mathrm{ik}, \mathrm{i}=1,2, \ldots \mathrm{c}$; sebagai elemen-elemen matriks partisi awal (U).

\section{HASIL DAN PEMBAHASAN}

\section{Hasil Tools dan GUI Matlab}

\section{Gambar Objek ke-1}

Sampel data yang digunakan dalam penelitian ini adalah objek beras sebanyak 2 gambar. Dalam proses clustering, image beras1 dijadikan sebagai Xi1 dan image beras2 dijadikan Xi2. Pengolahan data pada penelitian ini menggunakan bantuan sebuah software yaitu Matlab. Dari clustering yang dilakukan diperoleh hasil yaitu nilai fungsi obyektif selama iterasi, pusat cluster atau center serta derajat keanggotaan untuk setiap cluster pada iterasi terakhir. Dalam penelitian ini, untuk image beras1 proses iterasinya berhenti pada iterasi ke-16 karena nilai [Pt-Pt-
$1 \mid<\zeta$. Nilai fungsi obyektif pada iterasi terakhir yang diperoleh adalah 18001.108124. Untuk penelitian ini clustering menggunakan software Matlab dengan menjalankan di Command Window. Berikut iterasi yang di hasilkan :

Iteration count $=1$, obj. $\mathrm{fcn}=30584.153844$

Iteration count $=2$, obj. $\mathrm{fcn}=24914.732002$

Iteration count $=3$, obj. $\mathrm{fcn}=24913.521792$

Iteration count $=4$, obj. $\mathrm{fcn}=24899.905111$

Iteration count $=5$, obj. $\mathrm{fcn}=24755.216961$

Iteration count $=6$, obj. $\mathrm{fcn}=23616.924006$

Iteration count $=7$, obj. $\mathrm{fcn}=20075.867575$

Iteration count $=8$, obj. $\mathrm{fcn}=18124.570897$

Iteration count $=9$, obj. $\mathrm{fcn}=18003.808573$

Iteration count $=10$, obj. $\mathrm{fcn}=18001.222249$

Iteration count $=11$, obj. $\mathrm{fcn}=18001.118185$

Iteration count $=12$, obj. $\mathrm{fcn}=18001.109186$

Iteration count $=13$, obj. $\mathrm{fcn}=18001.108239$

Iteration count $=14$, obj. $\mathrm{fcn}=18001.108136$

Iteration count $=15$, obj. $\mathrm{fcn}=18001.108125$

Iteration count $=16$, obj. $\mathrm{fcn}=18001.108124$

$\mathrm{C}=\begin{array}{ll}0.0191 & 0.0124 \\ 0.1447 & 0.2342\end{array}$

Sebelum menemukan cluster pada iterasi, object gambar terlebih dahulu melalui proses HSV Image dan Image labeled by cluster index (gambar diberi label oleh indeks kluster). Kemudian cluster gambar object akan terlihat. Berikut proses HSV Image dan Image labeled by cluster index :

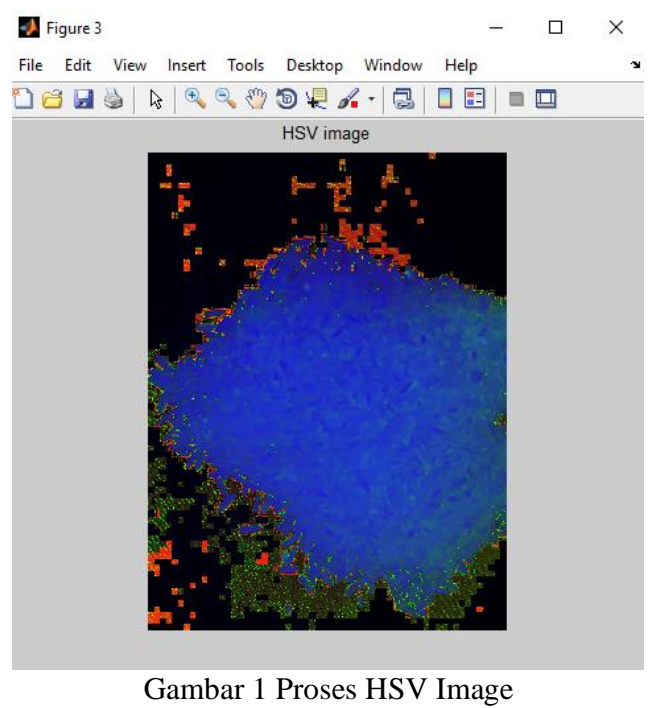

Penyebaran masing-masing cluster pada iterasi terakhir dapat dilihat pada cluster interface gambar beras1 dibawah ini : oleh indeks kluster). Kemudian cluster gambar object akan terlihat. Berikut proses HSV Image dan Image labeled by cluster index : 


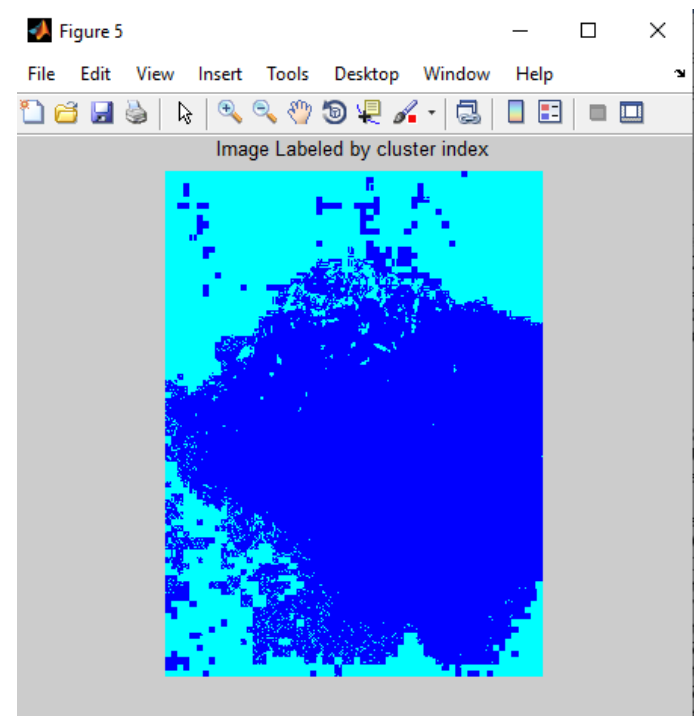

Gambar 2 Proses Image labeled by cluster index

Penyebaran masing-masing cluster pada iterasi terakhir dapat dilihat pada cluster interface gambar beras1 dibawah ini :

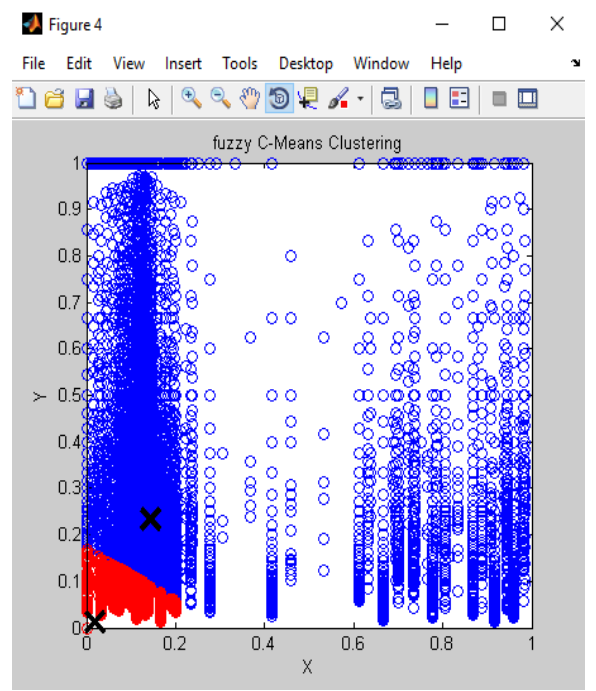

Gamabr 3 Posisi Cluster Iterasi terakhir

Keterangan :

Tanda $x=$ cluster 1

Tanda $x=$ cluster 2

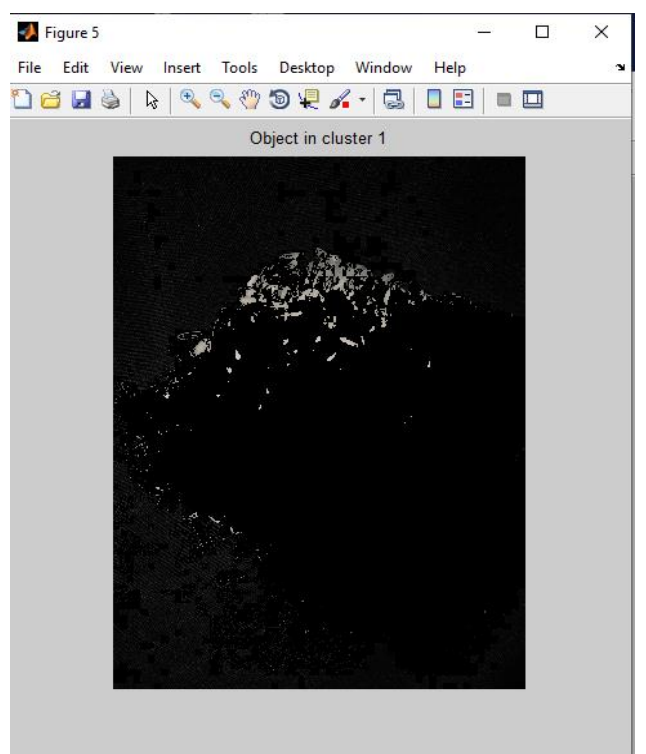

Gambar 4 Object in cluster 1

Detail Matriks U yang di hasilakan pada iterasi terakhir (iterasi ke-16) menggunakan fungsi Matlab yaitu :

Columns 1 through 156672 memiliki nilai yang sama

$$
\begin{array}{ll}
0.9932 & 0.9932 \\
0.0068 & 0.0068
\end{array}
$$

Columns 156673 through 156676

$\begin{array}{llll}0.5520 & 0.8437 & 0.6682 & 0.4114\end{array}$

$\begin{array}{llll}0.4480 & 0.1563 & 0.3318 & 0.5886\end{array}$

Columns 156677 through 15680

$\begin{array}{llll}0.0068 & 0.6424 & 0.6492 & 0.6117\end{array}$

$\begin{array}{llll}0.9932 & 0.3576 & 0.3508 & 0.5886\end{array}$

Columns 156681 through 156684

$\begin{array}{llll}0.5887 & 0.5910 & 0.0068 & 0.9238\end{array}$

$\begin{array}{llll}0.4113 & 0.4090 & 0.9932 & 0.0762\end{array}$

Columns 156685 through 15688

$\begin{array}{llll}0.9134 & 0.7877 & 0.6589 & 0.7135\end{array}$

$\begin{array}{llll}0.0866 & 0.2123 & 0.3411 & 0.2685\end{array}$

Columns 156689 through 15692

$\begin{array}{llll}0.9622 & 0.6326 & 0.9238 & 0.7849\end{array}$

$\begin{array}{llll}0.0378 & 0.3674 & 0.0762 & 0.2151\end{array}$

Columns 156693 through 15700

$\begin{array}{llll}0.0068 & 0.0068 & 0.0068 & 0.0068\end{array}$

$\begin{array}{llll}0.9932 & 0.9932 & 0.9932 & 0.9932\end{array}$

Columns 156701 through 156704

$\begin{array}{llll}0.8145 & 0.4732 & 0.8946 & 0.6102\end{array}$

$\begin{array}{llll}0.1855 & 0.5268 & 0.1054 & 0.3898\end{array}$

Columns 156705 through 156708

$\begin{array}{llll}0.5554 & 0.5554 & 0.5666 & 0.5615\end{array}$

$\begin{array}{llll}0.4446 & 0.4446 & 0.4334 & 0.4385\end{array}$

Columns 1228797 through 1228800

$\begin{array}{llll}0.0068 & 0.0068 & 0.0068 & 0.0068\end{array}$

$\begin{array}{llll}0.9932 & 0.9932 & 0.9932 & 0.9932\end{array}$

Pada iterasi terakhir (iterasi ke-16), pusat cluster $V k j$ yang dihasilkan dengan $k=1,2,3,4$ dan $j=1,2$ adalah :

$V k j=$

$\begin{array}{cccc}0.0068 & 0.0068 & 0.0068 & 0.0068 \\ 0.9932 & 0.9932 & 0.9932 & 0.9932\end{array}$

\section{Gambar Objek ke-2}

Untuk gambar obejk beras2 proses iterasinya berhenti pada iterasi ke-24 karena nilai $[\mathrm{Pt}-\mathrm{Pt}-1 \mid<\zeta$. Nilai fungsi obyektif pada iterasi terakhir yang diperoleh adalah 450038.640812. Berikut iterasi yang di hasilkan : 
Iteration count $=1$, obj. $\mathrm{fcn}=1247750.322495$

Iteration count $=2$, obj. $\mathrm{fcn}=1016649.627926$

Iteration count $=3$, obj. $\mathrm{fcn}=1016649.555319$

Iteration count $=4$, obj. $\mathrm{fcn}=1016648.866314$

Iteration count $=5$, obj. $\mathrm{fcn}=1016642.320700$

Iteration count $=6$, obj. $\mathrm{fcn}=1016580.138970$

Iteration count $=7$, obj. $\mathrm{fcn}=1015990.126633$

Iteration count $=8$, obj. fcn $=1010446.581506$

Iteration count $=9$, obj. $\mathrm{fcn}=962305.361798$

Iteration count $=10$, obj. $\mathrm{fcn}=725170.999716$

Iteration count $=11, \mathrm{obj} . \mathrm{fcn}=502509.448454$

Iteration count $=12$, obj. $\mathrm{fcn}=458662.672796$

Iteration count $=13$, obj. fcn $=451342.343524$

Iteration count $=14$, obj. $\mathrm{fcn}=450218.722763$

Iteration count $=15, \mathrm{obj}$. $\mathrm{fcn}=450062.520265$

Iteration count $=16$, obj. $\mathrm{fcn}=450041.757524$

Iteration count $=17, \mathrm{obj}$. $\mathrm{fcn}=450039.045224$

Iteration count $=18$, obj. $\mathrm{fcn}=450038.693175$

Iteration count $=19$, obj. $\mathrm{fcn}=450038.647585$

Iteration count $=20, \mathrm{obj} . \mathrm{fcn}=450038.641688$

Iteration count $=21$, obj. $\mathrm{fcn}=450038.640926$

Iteration count $=22$, obj. $\mathrm{fcn}=450038.640825$

Iteration count $=23$, obj. $\mathrm{fcn}=450038.640813$

Iteration count $=24$, obj. $\mathrm{fcn}=450038.640812$

$\mathrm{C}=\begin{array}{ll}0.1677 & 0.0941 \\ 0.6122 & 0.7570\end{array}$

Sebelum menemukan cluster pada iterasi, object gambar terlebih dahulu melalui proses HSV Image dan Image labeled by cluster index (gambar diberi label oleh indeks kluster). Kemudian cluster gambar

object akan terlihat. Berikut proses HSV Image dan Image labeled by cluster index :

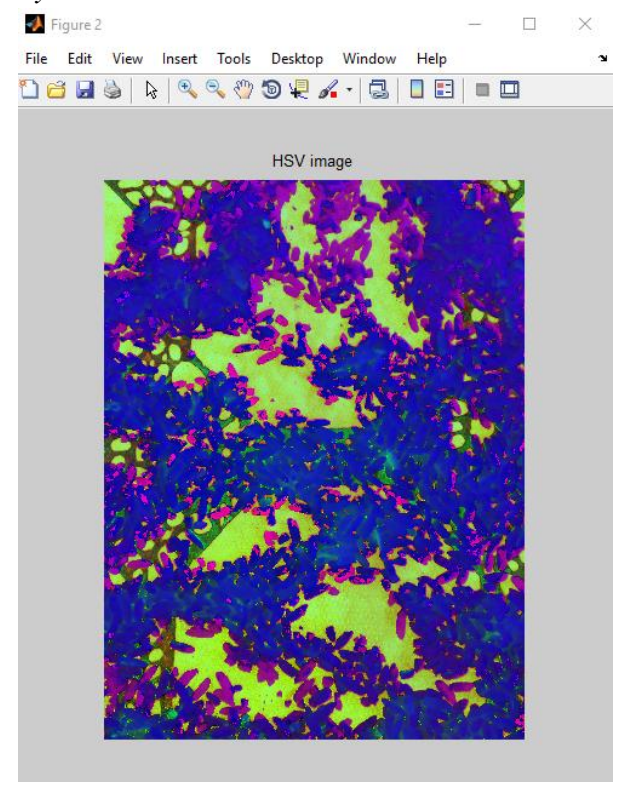

Gambar 5 Proses HSV Image

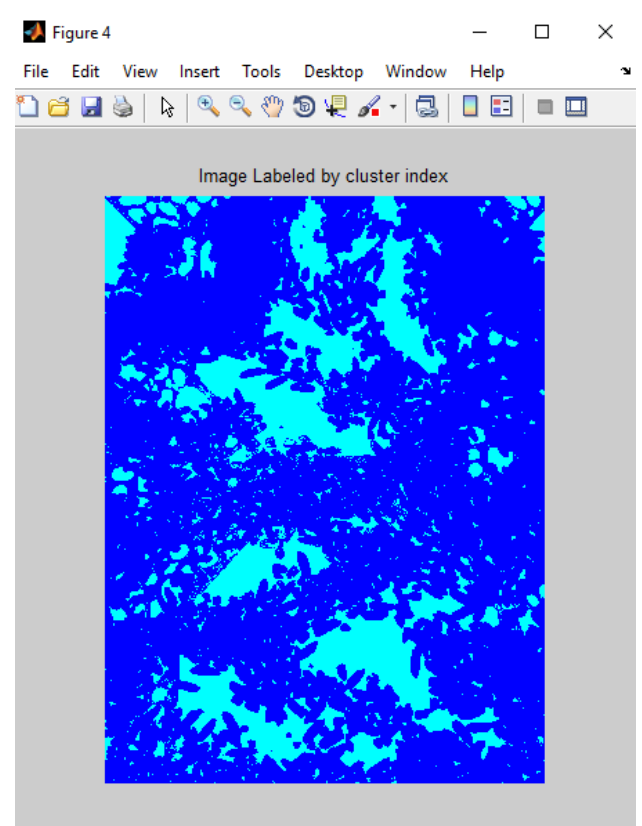

Gambar 6 proses Image labeled by cluster index

Penyebaran masing-masing cluster pada iterasi terakhir dapat dilihat pada cluster interface gambar objek beras 2 dibawah ini:

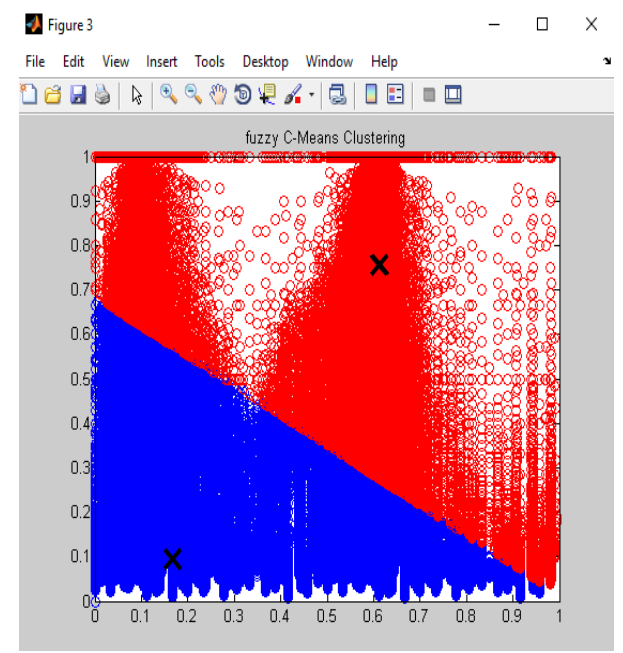

Gamabr 7 Posisi Cluster Iterasi terakhir

Keterangan : Tanda $x=$ cluster 1

Tanda $x=$ cluster 2 


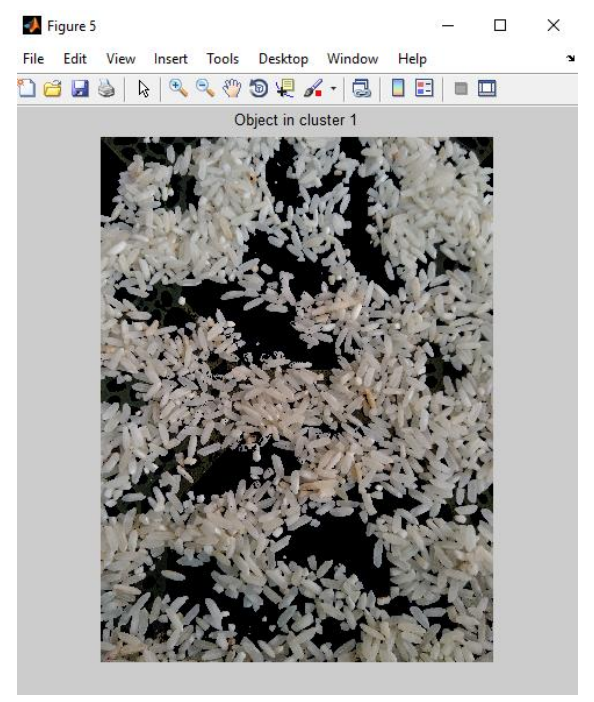

Gambar 7 Object in cluster 1

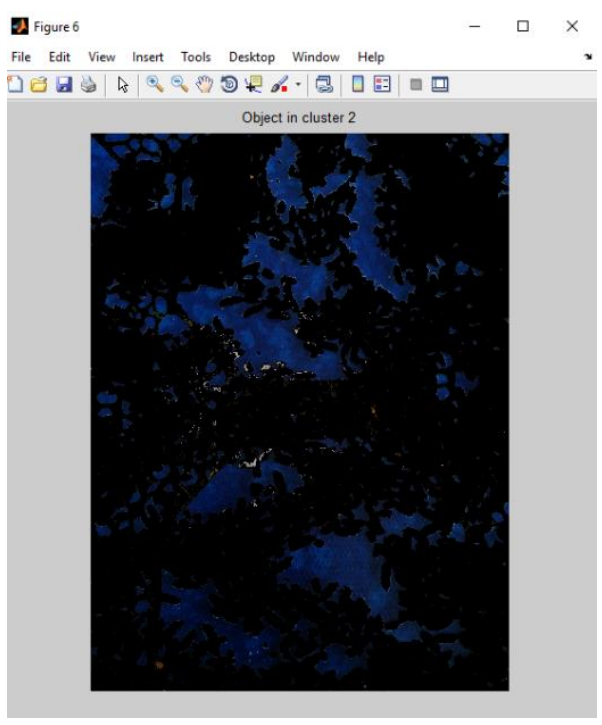

Gambar 8 Object in cluster 2

\section{Pembahasan}

Proses Clustering memerlukan sebuah proses untuk menentukan kelompok (cluster) mana yang di kategorikan beras bagus dan beras tidak bagus. Dalam penelitian ini akan mengelompokkan warna beras menjadi (2) cluster yaitu :

1. Cluster yang dikategorikan beras bagus.

2. Cluster yang di kategorikan beras tidak bagus.

Kemudian setiap cluster dibagi berdasarkan kriteria mana yang lebih cenderung ke warna beras bagus atau beras tidak bagus.

Iterasi pada percobaan ini berhenti pada iterasi ke-16. Hasil akhir clustering yang di peroleh adalah :

1. Cluster pertama memiliki pusat cluster (0.1448; 0.2343 )

2. Cluster kedua memiliki pusat cluster (0.0191; 0.0124)

Hasil clustering dapat dilihat pada Tabel 1.
Tabel 1. Hasil clustering untuk range gambar objek

\begin{tabular}{|c|c|}
\hline \multicolumn{2}{|c|}{ Warna Beras } \\
\hline B (Cluster 1) & TB (Cluster 2) \\
\hline Range & Range \\
\hline $0.1667-0.9877$ & $0.2-0.1667$ \\
\hline
\end{tabular}

Keterangan :

$$
\begin{array}{cl}
\text { B } & : \text { Bagus } \\
\text { TB } & : \text { Tidak Bagus }
\end{array}
$$

Tabel 2. Hasil clustering untuk range gambar objek 2

\begin{tabular}{|c|c|}
\hline \multicolumn{2}{|c|}{ Warna Beras } \\
\hline B (Cluster 1$)$ & TB (Cluster 2$)$ \\
\hline Range & Range \\
\hline $0.9583-0.9936$ & $0.6742-0.9596$ \\
\hline
\end{tabular}

Pada penelitian ini terdapat 2 gambar objek beras yang berbeda dan menghasilkan nilai clustering yang berbeda pula.

\section{KESIMPULAN DAN SARAN}

\section{Kesimpulan}

Berdasarkan pembahasan maka dapa di berikan beberapa simpulan diantaranya :

1. Algoritma Fuzzy C-Means dapat digunakan untuk mengelompokkan warna beras lebih halus dengan menerapkan derajat keanggotaan setiap elemen untuk masuk ke dalam kelompok-kelompok yang ada.

2. Pengujian sampel data dilakukan sebanyak 16 iterasi, di peroleh 2 kelompok berdasarkan warna beras, yaitu :

a. Kelompok pertama (cluster ke-1), berisi warna beras yang rata-rata sekitar $0.1448 ; 0.2343$.

b. Kelompok kedua (cluster ke-2), berisi warna beras yang rata-rata sekitar $0.0191 ; 0.0124$.

Range warna beras untuk gambar objek ke-1 adalah: 0.1667 0.9877

1. untuk kategori beras bagus dan $0.2-0.1667$ untuk kategori beras tidak bagus.

2. Sementara terdapat perbedaan pada range gambar objek ke-2 yaitu dengan range 0.9583 - 0.9936 untuk kategori beras bagus dan 0.6742 - 0.9596 untuk kategori beras tidak bagus.

3. Kemudian kedua gambar objek di cluster kan berdasarkan kriteria mana yang lebih di kategorikan dengan nilai terbesar pada jarak akhir merupakan cluster yang dikategorikan beras bagus, sedangkan cluster dengan nilai terkecil merupakan cluster yang dikategorikan beras tidak bagus. 


\section{Saran}

Saran dari penelitian ini yang dapat digunakan untuk mendapatkan tingkat akurasi yang lebih baik dalam penggunaan algoritma Fuzzy C-Means dalam penentuan warna beras untuk membantu tingkat pengetahuan masyarakat serta memberikan kontribusi yang lebih besar pada dunia riset, dan disarankan agar hasil penelitian ini dikembangkan sampai pada tahap Tools ataupun GUI dan memodifikasi algoritma Fuzzy C-Means dengan algoritma yang lebih baik ataupun dapat memodifikasinya dengan algoritma-algoritma terbaru.

\section{DAFTAR PUSTAKA}

Agustina, S. et al. (2012) 'Clustering Kualitas Beras Berdasarkan Ciri Fisik Menggunakan Metode K-Means', Clustering K-Means, pp. 1-7.

Elmande, Y. and Widodo, P. (2012) 'Pemilihan Criteria Splitting dalam Algoritma Iterative Dichotomiser 3 (ID3) untuk Penentuan Kualitas Beras: Studi Kasus Pada Perum Bulog Divre Lampung', Jurnal TELEMATIKA MKOM, 4(1).

Handayani, R. et al. (2011) '( Studi Kasus : Jalur Pmb Di It Telkom Bandung )', pp. 157-161.

Ilmiah, P. (2017) 'SISTEM DETEKSI PANEN PADI BERDASAR WARNA DAUN MENGGUNAKAN FUZZY C-MEANS CLUSTERING'.

Muhardi and Nisar (2015) 'Penentuan Penerima Penentuan Penerima Beasiswa Dengan Algoritma Fuzzy C-Means Di
Universitas Megow Pak Tulang Bawang', Jurnal TIM Darmajaya, 01(02), pp. 158-174. doi: 10.1093/beheco/arv114.

Pravitasari, A. A. (2009) 'Penentuan Banyak Kelompok dalam Fuzzy C-Means Cluster Berdasarkan Proporsi Eigen Value Dari Matriks Similarity dan Indeks XB (Xie dan Beni)', Seminar Nasional Matematika dan Pendidikan Matematika Jurusan Pendidikan Matematika FMIPA UNY, pp. 978-979. 